\title{
Agriculture as a Strategic Sector for the Purpose of Development of the Republic of Croatia
}

\author{
Jelena Legčević \\ Assistant Professor, Faculty of Law University of J. J. Strossmayer in Osijek \\ E-mail: legcevic@pravos.hr \\ Martina Matijaković, LLM \\ Faculty of Law University of J. J. Strossmayer in Osijek \\ E-mail:mmatijakovic@gmail.com \\ Eugen Jakopović \\ Student, Faculty of Law University of J. J. Strossmayer in Osijek \\ E-mail: eugen1307@net.hr
}

Doi:10.5901/mjss.2016.v7n4p

\section{Abstract}

In a time when the influence of the crisis is extremely strong and affects all segments of the society, it is necessary to recognize the importance of Croatian agriculture as an industry. It is necessary to put Croatian agriculture at a level of strategic branch of industry and act accordingly. Accessible data show that agriculture and food industry are proportionally important for Croatian economy since they contribute more than $9 \%$, to the overall GDP, more that $11 \%$, to the overall export and import and more than 20\% to overall employment. Data has been selected by a simple random sampling ranging from year 2009 through 2013. Significant impact of this paper is by using natural resources in a sustainable way Croatian agriculture has a possibility to place itself on the market as a country of top quality food, and as such also as a very healthy country where healthy food is becoming more and more important within global market relations. In order to develop agriculture, it is necessary to change the public perception, according to which farmers are considered to be a burden to the society, and it is necessary to take action regarding the tax reform (reduce VAT on food), allocate subsidies in a more fair way and seriously tackle the branding and geographical tagging of produce.

Keywords: agriculture, regional development, economy, natural resources

\section{Introduction}

Although we hear more and more in the media that tourism, industrial technologies and energetics should be the main drivers of the development of Croatia, agriculture is undoubtedly a branch of the economy with long history in these areas, and also has a great prospect, and as such can and must be one of the most important sectors bringing progress and prosperity to this country. Agriculture has an economical, social, environmental and cultural role in the development of Croatia. Although one gets an impression that the only task of agriculture is to produce food, its role is manifested through the development of tourism, energetic, trade, traffic, and through something that is particularly important, and that is the protection of rural areas and increasing the quality of living in these areas, something that has been much discussed in the European Union. Throughout history, Croatian agriculture followed different concepts of development which were affected and caused by technological discoveries, natural movement of population, but also by political and social relations.

The process of faster transformation of Croatian agriculture began in the late 1950s and lasted around 20 years. In this period high growth rates of production were accomplished, nature in crop and livestock production, labour productivity was increased. However, in the last two decades the physical volume of agricultural production has been decreasing. There are of course many causes for that: fragmented and plotted holdings, increasing number of uncultivated areas, war, insufficient investment in agriculture, certain inadequate agricultural policy measures, and similar (Čvarak, 2011). 
Accessible data show that agriculture and food industry are proportionally important for Croatian economy since they contribute more than $9 \%$, to the overall GDP, more that $11 \%$, to the overall export and import and more than $20 \%$ to overall employment. When European Union is concerned, however, the agriculture and food sector carry an inconsiderable importance, with its contribution of about 1\% to the main economic indicators (Franić, Jurišić, Gelo, 2014).

Policy creators have been trying to solve the existing problems of this sector using the available mechanisms of the Common Agricultural Policy (CAP) - the common policy of the European Union, but despite the efforts made in the last few years, Croatian agriculture is still uncompetitive when compared to the sectors of most European Union countries.

\section{Natural Potentials of the Agriculture in the Republic of Croatia}

Croatia is undoubtedly a land of rich and quality resources- a fertile land with good climate conditions, abundant water resources, large forests of excellent quality, large number of sunshine hours, and several types of climate in a relatively small spatial distance. The importance of agriculture lies not only in the traditional role of ensuring the nutritional needs of the population, but also in its role in protection of rural areas, ecological balance and preservation of traditional values, one could say the preservation of the life itself in rural areas. Rural area of the Republic of Croatia defined in numbers shows that $91,6 \%$ of the total surface of the Republic of Croatia is located in rural areas, $88,7 \%$ of settlements are located in rural areas, and $47,6 \%$ of the population in Republic of Croatia lives in rural areas. The conclusion can be drawn that little less than $50 \%$ of the population in our country occupies $91,6 \%$ of the territory of the Republic of Croatia, which literally means that almost half of the population cultivates almost the entire territory of the Republic of Croatia (Kravarščan, 2015).

Basic advantages of Croatian agriculture are three different geographical and climate areas: lowlands in the north and east, influenced by continental climate, coastal area in the south influenced by the Mediterranean climate, and the mountain region in the so called gorski (mountain) part of Croatia. Various types of climate, relief and soil enable the production of wide range of agricultural products, from agricultural and industrial crops to vineyards and continental and Mediterranean fruits and vegetables. There are conditions for cultivation of almost all most popular household food products.

Low level of environmental pollution enables the development of organic production, which was partly recognized, and in the period from 2007 to 2013 the areas for organic production experienced a five-fold increase. However, portion of areas under organic production in the entire agricultural land that was used in the year 2013 amounted to only 3,12\% ("Annual Report on the State of Agriculture", 2014).

Abundance of drinking water is also one of great comparative advantages of this country, and it is closely related to the development of agriculture in the form of increase of productivity by means of irrigation, but also through development of organic agricultural production, which will surely take the main role in the development of a sustainable development concept. According to the UNESCO'S report on water supplies made by monitoring the situation in 188 countries of the world, Croatia ranked third in Europe; only two northern countries are more abundant in water: Norway and Iceland. According to the same report, Croatia annually disposes of 32.818 cubic meters of renewable drinking water per capita, and according to that, it is among 30 countries richest in water in the world. Besides that, Croatia is among few countries which guarantee and provide drinking water for its citizens by means of its public water supply systems ("Croatia is the third country in the world according to her water resources", 2007).

An increasingly important significant advantage is the fact that Croatia is a $\mathrm{GMO}^{1}$-free country. All Croatian counties have declared that they are areas free of GMO; Gm crops cannot be found at all in the territory of Republic of Croatia (Gnjidić, 2015). There is only one GMO culture grown in the European Union- Monsato corn MON 810. It is cultivated in five member states, at about 180 thousand hectares, most of which in Spain at 137 thousand hectares, while the rest is grown in Portugal, Czech Republic, Romania and Slovakia (Špoljar, 2015). Despite the favourable natural resources, the historical, organizational, economical and institutional reasons explain the complex situation in agriculture and rural areas.

\section{Main Reasons for the Poor State in Agriculture}

Croatian agriculture is in a poor state with only little number of producers that have a clear and financially stable situation, accompanied by a vision and plans for further expansion and managing their property. We can all agree that the situation

\footnotetext{
${ }^{1}$ The term genetically modified organism refers to all organisms who segenetic material has been changed in a way that does not occur naturally but by means of techniques of genetic engineering.
} 
is indeed difficult, as can be seen from all import-export balances; decreasing number of livestock and family farms (OPG). In the year 2013, cattle breeding included 397.000 animals, and in 2010 497.000, which is a decrease of 100.000 animals in a period of three years. Pig farming in the year 2013 included 1092000 fatlings, and in 2010 that number was far higher - 1521000 pigs. The decrease is registered also in poultry farming- in 2013, there were 12637000 chickens, and three years ago there were 13470000 chickens ("Catastrophic data on Croatian agriculture", 2015). Comparing to average farm of EU-27, average farm in the Republic of Croatia uses $61,2 \%$ less agricultural land, 60,8\% less livestock units, and achieves 64,4\% lower value of standard results ("Annual Report on the State of Agriculture", 2014).

Although such state in agriculture is highly complex, and no answer is unambiguous, we should look for the causes for this state and lack of competitiveness on the market in several areas. One of these areas is undoubtedly the state in which agriculture found itself after the war, and this state includes numerous farmlands that are covered in mines, the fact that our livestock fund is ruined, machinery that remained at a very modest level, and the farmers are insufficiently trained, which is a burning issue which has not been resolved till today. Besides, the agricultural sector lags behind in investments due to lack of quality resources, which is a consequence of the lack of interest for the placement of loans in agriculture in the banking sector, because, among other things, there is less profitability in agriculture, higher risk, and lack of quality guarantee that the farmer must provide (Gelo, Gelo, 2007). Mentioned problems are especially true of Slavonia, which is the most developed agricultural area in Republic of Croatia. A consequence of the war is a complete change of the system, both regarding the government and agriculture. Agricultural conglomerates have been abandoned and privatisation takes place, large agricultural conglomerates are divided into smaller business units, which in most cases did not prove to be a good solution, for both the country's economy and for the farmers themselves. Although agricultural conglomerates were not an ideal solution or an ideal organizational structure, these changes should not have been made without a clear strategy what to do after they have been changed, that is, what type of agriculture do we want? The problem with privatisation is that agricultural conglomerates were privatised in such a way that their financial situations were made very difficult through irrational management and they were afterwards sold at low prices, which at the end cased conglomerates to be divided into smaller companies which later did not succeed to survive on the market. The problem also arose due to the fact that by changing the organizational structure the farmer was left on his own, which meant that that from that point on, he had to think about the market, about placing his products on the market, which was not the case before. The greatest problem, which is then followed by all other problems, is lack of a clear vision and strategy in agriculture. All the strategies which have been written so far have not yet been implemented because the government, experts for agriculture and farmers have not reached a consensus. Particular interests of certain groups prevailed- groups wanting to make Croatia a country which cannot produce enough food to satisfy its own needs and has to import a lot. Dependence of Croatia on import of food is almost $50 \%$, while the $\mathrm{EU}$ is independent. In the last few years the deficit in import at the annual level has amounted to one billion US dollars, or 2,7 million US dollars per day, while in the 1980 s we realized 800 million surplus (Šajn Rak, 2013). There is no clear position on what we want and which type of production do we want to engage in. Is it organic, intensive or integrated agriculture? Which sectors do we want to encourage? The fact is that the dairy industry is in very poor condition, although $90 \%$ of the milk produced by domestic manufacturers falls in the category of top quality according to all European standards. The next big issue refers to the statutory legal framework, which is from the farmers' point of view highly bureaucratized, complex and complicated, and on the other hand does not protect domestic production enough, which can be clearly seen in example of import quotas for agricultural products which were negotiated with the European Union. An example of a thoroughly wrong agricultural import policy can be demonstrated most clearly in the example of pig farming. One of the main issues is of administrative nature and it refers to the expiration date for meat. There are no regulations in Croatia that govern that, so for example, the expiration date for frozen meat is six months in Germany, but twelve months in Croatia. Experts in Croatian Institute for Public Health and Croatian Food Agency have pointed out in the media that the expiration date for frozen meat is twelve months ("Shelf life of frozen pork", 2014). In other member states of the European Union the processors are required within six months to either sell the meat or process it, or if they do not manage to do that, they must incinerate it, for which they of course have to pay. Since the expiration date for meat is another six months in Croatia, it enables our importers, usually large retail chains, to import the meat which is bought at a very low price in these countries because it is considered waste there, so the meat is then imported in Croatia and placed on the shelves. By doing that, they destroy not only the domestic producers but also the consumers, because the meat they sell is of very poor quality. This type of meat has a long-term multiple negative consequences on the society from reduction in quality of life to the increase in health problems. This is an example in which the legislation of the country favours to the importers by means of laws that had been adopted, and at the expense of their own production and producers. The consequence of these regulations is a drastic reduction in number of pigs. This is supported by the fact that there are only 752.118 pigs in Croatia, while in 2010 there were 925.118, and in 2009 1,4 billion pigs (Rupčić, 2014). Similar situation can be found in the dairy industry, where 
there is no state control over the market. Precisely for that reason, dairy industry is the best example, being our most complex agricultural branch. We import milk at lower prices from neighbouring countries where subsidies per one litre of milk are much higher, and in that way we destroy domestic dairy production. The game of hide and seek takes place, and big businesses are destroying farmers and their production. In comparison to September 2013, milk production has fallen by $12,1 \%$ and domestic needs have been fulfilled through import (I.Ć., 2014).

As previously said, Croatia disposes of all resources needed for self-sufficient production of food products, but the data on import indicate otherwise. In the year 2013, we imported agricultural and food products worth 2.127,8 million EUR, and exported agricultural and food products worth 1.205,1 million EUR, achieving a deficit of 922,7 million EUR. In 2013 the coverage of imports by exports of agricultural and food products was the lowest in the period from 2009 ("Annual Report on the State of Agriculture", 2014). The subsidies system was organized fairly well but lacked control, because of which the subsidies did not yield the expected results. The subsidies were used by those who found themselves in agriculture by chance, that is, those who recognized the situation in which one can earn money in an easy and fast way. A sociological problem also emerged in the society, where farmers are presented in a bad light, or to be precise as if they lived of the society and were parasites in the society, which influenced greatly the way of thinking and the motivation of the people to engage in this extremely hard work. The consequence of these problems is closing of family run farms. In 2007, family run farms owned around $84 \%$ of the agricultural land and most of the livestock (Golja, 2013). Despite of that, only $20 \%$ of the area was cultivated. That fact is alarming, and in 2012 agricultural production decreased by 9,9\% ("Last year around 3 thousands family run farms was closed", 2014). In 2013 more than three thousand farms was closed, most of all due to decrease in prices of agricultural products under the pressure of industry and free market, irregular payment of subsidies and unpredictable climate conditions ("Last year around 3 thousands family run farms was closed", 2014).

The issue of consolidation of holdings is also one of major hurdles in development of agriculture because farmers can hardly be competitive if they do not have adequate areas of land at their disposal. According to the classification of countries in five groups, Republic of Croatia with 0,21 hectares of farmland per capita belongs to the group of countries which are poor in agricultural land (from 0,10 to 0,32 hectares per capita) (Čvarak, 2011). The provision of the Ministry on Prohibition to sell Agricultural Land allows only a concession of state agricultural land to a period of 50 years, and through this form of management only 500 hectares of state agricultural land provided for. As an example, according to the Croatian Bureau for Statistics (DZS), in 2013 farms cultivated 1,25 million hectares of agricultural areas, which represents a decrease when compared to the year 2010 when 1,316.000 hectares of land were cultivated ("Catastrophic data on Croatian agriculture", 2015 ). When it comes to comparison between the farmers from the European Union and Croatia, one can clearly see a discrepancy. An average farm (PG) in Republic of Croatia uses 8,9 hecaters of agricultural land less than an average farm of EU-27, or if presented through relative indicators, an average farm surface in Republic of Croatia is $61,2 \%$ smaller than the average surface of a farm in EU-27 ("Annual Report on the State of Agriculture", 2014). This fact indicates that there is a need to solve the issue of state farms and the need for consolidation of holdings, which would enable better production planning and more rational resources consumption. Average value of agricultural production per farm is 9 thousand Euros, and is $60 \%$ smaller than the EU average. $60 \%$ of family run farms reach an annual production value which is less than 4000 Euros. These data show that agricultural land is not sufficiently utilized, and the position Croatia has regarding the surfaces that are to be converted into arable land must be considered a comparative advantage, but it is not a guarantee for success. Example for that are the countries in the South of Europe, like Greece and Portugal, which are smaller in surface, but are more successful in production of certain agricultural produce.

Specificity of Croatian model of agricultural development can best be seen in the fact that $0,5 \%$ of the total number of farms (900 farms) that use $1 / 3$ of the total production resources realise $1 / 3$ of the total agricultural subsidies, while at the same time $90 \%$ of family run farms realise $1 / 4$ of the subsidies. Particularity of this agricultural policy has caused a relationship in which there are chain stores that are at the same time also the biggest national producers (they get the highest subsidies), largest traders and largest importers. In this way, the farmer is put in a difficult position, where a small group of interest lobby groups creates prices and the situation on the market.

\section{Agricultural Land- The Most Valuable Resource}

The land is the basic factor of production and the object of operation in agriculture. It is not only necessary, but also a unique, irreplaceable, indestructible and immobile factor of the mass agricultural production (Grahovac, 2007). Small estates are predominant in Croatian agriculture. The undivided opinion shared by the professional and general public that fragmented and plotted holdings, together with the undeveloped agricultural land one of the key reasons for lagging 
behind and lack of competitiveness of Croatian agriculture (Grahovac, 2006). By using undeveloped surfaces in the last twenty years (in total 814.225 hectares if state and private property) for the purposes of consolidation of holdings, it is possible to acquire a predominant number of farms bigger than 15 hectares, which would also contribute to achieving competitiveness of their products on the market. In consolidated farms, that is, by putting the 814.255 hectares of land that has been non-arable up until now into use, there will be possibility to employ people in agriculture. Estimates show that around 600.000 new positions could be opened in this way. That would not only benefit the agriculture, but it would also fulfil conditions for economic recovery of Croatia (Tomić, 2014). However, managing the agricultural land in the way it has been done up until now has not achieved the desired nor adequate effect. Although The Agricultural Land Act from the year 2013 should significantly improve the situation, faults were soon identified. Namely, the applied model has not resolved the issue of uncultivated agricultural land, the advantages that had been negotiated with the EU concerning the Prohibition to sell Land to Foreigners, which was at force in almost all states during the accession period, were annulled in such a way that also domestic farmers were not able to buy properties. Another issue regarding this method is putting family run farms and large companies in the same position, whereby large companies take precedence over family run farms through their economic programmes. A big disadvantage is also the non-existence of clearly voiced benefits the domicile population should have when buying or leasing of state agricultural land. Due to that fact, cases have emerged where large business systems receives large land areas in remote areas, and the local population is having difficulty getting one. This way of managing is not beneficial for agriculture, and also not for the viability of rural areas and the protection of life, and it represents a serious obstacle to consolidation and expansion of family run farms, which is a prerequisite for their development.

The advantages of large farms can be summarized in a few points: higher productivity of workforce and means of production; more rational and complete usage of material resources and workforce; higher quality of certain procedures that are used in the cultivation of plants and animals: numerous possibilities of applying the results of scientific and technical progress; generally higher production per unit capacity; lower unit cost of production; higher level of professional development and labour division; more favourable position in the market of final products and inputs of agricultural production, as well as in the financial market; more profitable production (Grahovac, 2006). The proposition that should be used refers to enabling the domestic farmers to buy state land, but according to strictly proscribed conditions, to ensure that the land actually goes to the people who cultivate it, live in rural areas and employ in their area. The land should be limited to 1000 hectares available for buying and 1000 hectares available for selling in a respective county, whereby the right to use subsidies would belong exclusively to the owners of the land. It is necessary to balance the prices of leasing the state agricultural land among old and new lease-holders. There is a big number of examples in practice where in the same cadastral municipality one pays up to 5 times lower price per unit area, only because the lease contract had been signed earlier in comparison to when somebody else signed it. Local governments bear a big part of the responsibility, and there are municipalities and cities where not a single square meter state-owned agricultural land has been provided for, that is, they are either sold or given in concession. By increasing the arability of these up until now neglected farmlands, and by consolidating the farms, significantly better conditions for the realization of effective agriculture can be achieved and its products can be placed on the market.

\section{European Agricultural Policy- Challenges for Croatian Agriculture}

The Common Agricultural Policy, CAP is a set of measures and programmes of agricultural subsidies in the European Union. The aim of this policy is to ensure reasonable prices and acceptable quality of agricultural produce for European consumers, satisfactory income for EU farmers and preservation of rural heritage. CAP is one of the most important policies implemented by the EU, and almost half the EU budget is spent on it (Kesner-Škreb, 2008).

CAP has significantly developed since its beginnings in 1962, and is still developing. In the last decade of the $20^{\text {th }}$ century, a process of reforms has begun. The first reform from 1992 reduced internal market subsidy and introduced direct payments by land area and livestock. A complete turnover from price support towards direct payments happened in 1999 as a part of EU Agenda 2000. ${ }^{2}$ Following the period after the signing of the Stabilisation and Association Agreement with the European Union Republic of Croatia started adjusting all segments of the Croatian agricultural policy to CAP by passing the Law on Agriculture (Official Gazette 66/01) and the The Act on State Aid in Agriculture, Fisheries and Forestry (Official Gazette 87/02) which at the same time represents an extremely important reform, because it also includes the structural policy measures (Ljubaj, Jež Rogelj, Franić, 2015). The most ambitious reform and the reform

${ }^{2}$ A new stage to build on the 1992 reform which refered to a new adjustment of internal prices on the world market, introduction of eceological conditions for receiving subsidies and budgetary stability within the financial framework for the period 2000 to 2006. 
which most influenced Croatian agricultural policy is the one from the year 2003 (Mid Term Review - MTR), which separates the payment from the production, also increases the share of rural development and introduces environmental standards, and standards of economy management as prerequisites for receiving single payments. The influence of this reform and the one from the year 2008 (Health-Check) as a consolidation of the framework for the 2003 reform can be recognized in the 2009 and 2010 Act on the State Aid (Official Gazette 83/09, Official Gazette 92/10). Both acts provide coupled payments, tor rather subsidies. In 2009 coupled payments included special and other payments in crop production and per head of livestock, payments for keeping and slaughtering cattle, additional payments for production of reproduction material, payments for milk and other payments in livestock breeding. A year later coupled subsidies payment becomes more and more directed towards environment protection and creation of added value (Ljubaj, Jež Rogelj, Franić, 2015). The 2013 reform was the final phase of the still unfinished adaptation process. This reform determined main guidelines and strategic goals of CAP for the period 2014-2010: converting decoupled aid into a multifunctional support system; consolidating the two pillars of the CAP (the first pillar, which funds direct aid and market measures through the EAGGF; and the second pillar, which covers rural development through co-financing arrangements); Consolidating single $\mathrm{CMO}$ tools to provide safety nets for usage solely in the event of price crises or market disruption, and more integrated, targeted and territorial approach to rural development (Massot, 2015).

Among the most important concepts supported by the new CAP is the strengthening of environmental sustainability ("greening") and 30\% spending of direct payments with the purpose of improving the use of natural resources. Encouraging young people to engage in agriculture is supported through additional subsidies ranging from $25 \%$ per hectare for a period of 5 years. At the national level of Croatia it amounts to $2 \%$ of the total resources for agricultural subsidies. Small farmers will be given a single annual subsidy in the amount from 500 to 1000 Euros, regardless of the farm size. Payments to the farmers who do not engage in agriculture, and accordingly do not generate profits, will be suspended or direct payments, or rather cofounding in agriculture, will be reduced. Each farm will have a limit of 300.000 Euros per year (together with deduction of salary expenses for the previous year) for cofounding in agriculture. Cross compliance conditions will have to be met for each farm. Amount of the support within the CAP can vary greatly from one farm to the other, and also from one state to the other. 2013 reform strives to reduce the discrepancies in the redistribution of subsidies via EU supports ("Co-funding in agriculture", 2015). Regardless of how simple it may seem, the application of European models in Croatia would not function and is not functioning simply and without any problems due to previously mentioned structural limitations in the sector. Local farmers fear that they are not going to be able to fulfil strict criteria of European funding due to lack of their own capital, ability, will to cooperate and initiative needed to start local (rural) projects (Franić, Jurišić, Gelo, 2014).

In the financial period from 2014 to 2020 Croatia has at its disposal slightly more than 2.26 billion Euros from the European Agricultural Fund for Rural Development. It is important to highlight that member states choose measures adjusted to their needs, and they manage their programmes on they own, while the projects are co-financed by the European Union ("European agricultural policy", 2015). Therefore, the state has to be an active driver of reforms which will protect the farmers throughout all the phases of their work and action, distribute the aids to active farmers more righteously, and in cooperation with them work on improving the competitiveness of the agricultural sector, environment and rural areas, as well as life in rural areas.

\section{Recommendations and Possible Solutions for Development of Agriculture}

In order to develop agriculture it is necessary to develop the local market. In order to achieve that, it is necessary to shorten supply chains and reduce the number of steps from the producer to the consumer. It is necessary to stimulate and encourage doorstep selling, which, we could say, is the only way in today's state concept to reach authentic, organic food, and as such it is a guarantee that the product is of top quality. It is necessary to encourage and develop short supply chains as much as possible, such as: direct selling, farmers markets, local dairies... Regulate the market by means of normative and administrative measures, which would increase the control of the products (example of frozen meat), and on the other hand liberalize laws referring to direct production on farms, for which there are great examples in EU countries. The production of products with quality label, designation of origin and geographical indications should also be one of the priorities in the strategy of agricultural development.

Concrete steps that should be taken for development, not only regarding agriculture, but also the entire economy of the Republic of Croatia refer to ("European agricultural policy", 2015):

1. Primary agricultural production aimed at fulfilling the needs of domestic market and export, development of the food industry which has to create additional value from which workplaces will be financed, and it also needs to be a service to primary production which employs a significant number of people in itself, 
2. It is necessary to create competitive agriculture which will be able to respond to the common European market, which can be achieved only by uniting and supporting farmers by means of subventions

3. it is necessary to protect domestic production by strengthening the consumer awareness regarding buying domestic products, but also through more strict import conditions, especially for fresh meat and vegetables,

4. Investing in development of rural tourism and rural areas, maintaining the population and self-employment through rural tourism,

5. Preserving the existence of the Croatian village by turning the production of the Croatian village into a foundation for development of rural tourism through preserved environment and natural resources.

Reducing the VAT on food is a part of a fiscal policy that could directly influence domestic production and improve the social situation of citizens. This step would introduce a proposed rate of VAT for food of $10 \%$ at the most, and for organic food and Croatian products carrying the label of EU quality of up to 7\%. In this way, domestic production and consumption would be stimulated, and people would consume healthier food.

It is also of great importance to restructure agricultural producers in such a way that agricultural producers cultivating smaller agricultural areas opt for production of fruits and vegetables which can generate higher revenue per unit area or feed with production of meat and milk, because profitable production of grain and industrial crops cannot be realised at smaller areas ("Information on the state and problems", 2013). Agricultural production not accompanied by necessary manufacturing capacities does not create the added value which is the basis for overall economic development, and it is therefore necessary to build agricultural capacities and link the producers to make final products for which there is a market. It is also necessary to intensify the construction of agricultural infrastructure and production capacity ("Information on the state and problems", 2013), and in order to make it feasible it is necessary to ensure a more quality credit lines. We should not forget that we have at our disposal large sums of money from the European agricultural funds, which we can and should use.

In addition to strategies for changes in production practices, sustainable agriculture also requires a commitment to changes and adjustments of public policies, economic institutions and social values. A complex and continuously variable relationship between agricultural production and the wider community must be taken into consideration in programmes for these changes. Agricultural system expands far beyond the issue of agriculture and includes interaction between the individual and the institutions, which often have opposing and competitive goals (farmers, researchers, suppliers of inputs, agricultural workers, unions, agricultural advisory service, processors, traders, consumers, and politicians). Since new technologies bring economic, social and political changes, relationships between all the participants change over time. It is essential to educate farmers and form clusters with the purpose to increase competitiveness. The government should act as a moderator and try to regulate relationship between all the participants through clear regulations and provisions, certainly not to the extent that it regulates the market, but it needs to determine a single legal framework which would restrain one interest group from realising extra profit in comparison to the other, which happened a few times in Croatia, the best example for that being the purchase of wheat.

Broad range of strategies and approaches is necessary for creating sustainable agricultural and food systems. It includes specific efforts during a long-term period to change policies and practices referring to reforms of key institutions, revision of economic priorities and reviewing of adopted social values (Franić, Kumrić, 2008-2009)

\section{Conclusion}

In a time when the influence of the crisis is extremely strong and affects all segments of the society, it is necessary to recognize the importance of Croatian agriculture as an industry. It is necessary to put Croatian agriculture at a level of strategic branch of industry and act accordingly. Croatia indisputably has top quality natural resources along with prerequisites for successful agricultural production. Top quality soil, uncontaminated water, natural biological diversity, and excellent geographical position can and must be a guarantee for agricultural development on the principles of sustainable and organic farming. Agriculture is a branch of industry which is colloquially called "factory under the sky", and when all the circumstance are taken into consideration, it is obvious that this branch of industry carries the greatest risks that cannot be influenced, alongside all the risks concerning the market and production. It appears that for these reasons the administrative decisions made by the ministries and the government have a large influence on the development of the entire agricultural sector. By joining the EU we have witnessed a decline in competitiveness of agricultural producers, but also a justification repeated like a mantra which serves as a justification for all the unresolved issues in agriculture, since we are now in a single market and producers are left to functioning of market mechanisms. The best example of this kind of operation is evident from the land policy which does not correspond to the needs of the farmers. There is a large discrepancy between family run farms and companies which among other things engage in 
agricultural production. As in many other sectors of industry, fundamental and structural reforms are also needed in agriculture. It is necessary to make a clear strategy defining the way we want to take, what kind of production do we want? Who is the key agent in the process of development - big companies or family run farms? In this globalisation era, through its agriculture Croatia has the possibility and the chance to become a unique and advanced country in which it is absolutely possible to produce top quality food for its own needs, but also for export. By using natural resources in a sustainable way Croatian agriculture has a possibility to place itself on the market as a country of top quality food, and as such also as a very healthy country. Healthy food is becoming more and more important within global market relations. In order to develop agriculture, it is necessary to change the public perception, according to which farmers are considered to be a burden to the society, and it is necessary to take action regarding the tax reform (reduce VAT on food), allocate subsidies in a more fair way and seriously tackle the branding and geographical tagging of produce. We should also bear in mind that after joining the EU and after the implementation of the Common Agricultural Policy, in addition to large sums of money Croatia has at its disposal from the agricultural funds there are also measures for strengthening of its position on the market - a chance we should not miss out on. Research shows that Croatian agriculture and food production can exist and develop in European political and economical circumstances, which contributes to the Croatian identity as a whole.

Agriculture is a very specific and demanding branch which unites entrepreneurship, agriculture, economy, but it is also a branch which together with the already mentioned reforms has potential and can and must be a key engine of economic growth of the Republic of Croatia.

\section{References}

Bašić, F., Tomić, F. (2014). Agriculture as a Potential for the Development of Croatian Economy, Zagreb: HAZU.

Čavrak, V. (2011). Economy of Croatia, Zagreb: Politička kultura.

Defilippis, J. (2005). Agriculture and Development, Zagreb: Školska knjiga.

Franić, R., Jurišić, Ž., Gelo , R. (2014). Food production and rural development- Croatian perspective within the European context, Agroeconomia Croatica 4:1, 16-24

Gelo R., Gelo T. (2007). Croatian Agrculture in the context of Croatia's accession to the European Union, Scientific Conference: Agriculture and Economic Development with regard to the 80. Birth Anniversary Academician Vladimir Stipetić, 1, 15-31

Grahovac, P. (2007). Agricultural Land and Agricultural Policy, Scientific Conference: Agriculture and Economic Development with regard to the 80. Birth Anniversary Academician Vladimir Stipetić, 1, 33-53

Grahovac, P. (2006). Regional Features of the Ownership Structure in Croatian Agriculture, Conference Proceedings form the Faculty of Economy in Zagreb, 4, 23-44

Kesner-Škreb, M. (2008). Common Agricultural Policy of the European Union, Financial Theory and Practice 32:4, 543-545

Ljubaj, T., Jež Rogelj, M., Franić, R. (2015). Influence of Reforms of the Common Agricultural Policy on Croatian Agricultural Support in the Period from 2001. - 2013, 50th Croatian and 10th International Symposium on Agriculture, Opatija, Croatia, 109-113

Tomić, F. (2014). States and Measures for Improvement of Croatian agriculture in the Light of the Accession to the European Union, Civitas Crisiensis, 1, 129-142

\section{Web sources:}

Annual Report on the State of Agriculture in 2013 Republic of Croatia, (2014), Ministry of Agriculture. [Online] Available: http://www.mps.hr/UserDocsImages/publikacije/2014/Zeleno\%20izvjesce\%202014.pdf (July 21, 2015)

Catastrophic data on Croatian agriculture, (2015). [Online] Available: http://www.agroportal.hr/vijesti/hrvatska/porazni-podaci-o-hrvatskojpoljoprivredi/ (January 15, 2015)

Co-funding in agriculture, (2015). [Online] Available: http://www.pravaideja.net/sufinanciranje-u-poljoprivredi/ (July 22, 2015)

Croatia is the third country in the world according to her water resources, (2007). [Online] Available: http://www.poslovni.hr/domacekompanije/hrvatska-treca-u-europi-po-bogatstvu-vode-51234 (February 20, 2015)

European agricultural policy, (2015). [Online] Available: http://www.ekonomskiportal.com/europska-poljoprivredna-politikal (July 22, 2015)

Franić, Ramona, Kumrić, Ornella, (2008-2009), Agricultural and rural policies II. [Online] Available: https://bib.irb.hr/datoteka/382584.ARP_II_-_ispitni_materijali_120109.pdf (July 24, 2015)

Gnjidić, Lidija, (2015), EU gives in to the GMO, while Croatia remains 'clean'. [Online] Available: http://slobodnadalmacija.hr/Hrvatska/tabid/66/articleType/ArticleView/articleld/262939/Default.aspx (February 2, 2015)

Golja, Ana, (2013), Food Sovereignty Forum in Croatia. [Online] Available: http://zmergo.hr/2013/10/ (October 11, 2014)

I.C., (2014), Disgrace: This is why ten farms a day experience failures in Croatia. [Online] Available: http://www.index.hr/vijesti/clanak/sramota-evo-zasto-u-hrvatskoj-dnevno-propada-desetak-poljoprivrednihgospodarstava/664548.aspx (December 15, 2014)

Information on the state and problems of the agricultural production in the area of Osijek-Baranja count, (2013). [Online] Available: 
http://www.obz.hr/hr/pdf/2013/4_sjednica/04-

informacija_0_stanju_i_problematici_poljoprivredne_proizvodnje_na_podrucju_OBZ.pdf (July 24, 2015)

Kravarščan, Ljubica, (2015), LEADER for rural areas. [Online] Availab̆le: http://www.savjetodavna.hr/vijesti/37/3661/leader-za-ruralnopodrucjel (February 15, 2015)

Last year around 3 thousands family run farms was closed, (2014). [Online] Available: http://www.agroportal.hr/vijesti/hrvatska/proslegodine-zatvoreno-preko-3-tisuce-opg-ova (February 10, 2014)

Massot, Albert, (2015), Instruments of CAP and their reforms. [Online] Available: http://www.europarl.europa.eu/atyourservice/hr/displayFtu.html?ftuld=FTU_5.2.3.html (July 21, 2015)

Rupčić, Zdenka, (2014), A large decrease in the number of pigs and milk production [Online] Available: http://www.agroklub.com/stocarstvo/velik-pad-broja-svinja-i-proizvodnje-mlijeka/6018/ (February 10, 2014)

Shelf life of frozen pork is 12 months, (2014). [Online] Available: http://www.glasistre.hr/vijesti/pula_istra/rok-trajanja-zamrznutesvinjetine-je-12-mjeseci-470985 (January 10, 2015)

Šajn Rak, Jolanda, (2013), Croatian dependence on imported food surges 50 percent. [Online] Available: http://www.vecernji.hr/hrvatska/hrvatska-ovisnost-o-uvozu-hrane-skocila-vec-na-50-posto-607997 (January 10, 2015)

Špoljar, Sandra, (2015), EU countries will be able to protect its areas from GMO. [Online] Available: http://www.agroklub.com/poljoprivredne-vijesti/drzave-eu-moci-ce-svoj-prostor-stititi-od-gmo-a/17037/ (July 28, 2015) 